\title{
Development of the rumen digestive functions in lambs placed in a sterile isolator a few days after birth
}

\author{
G Fonty 1-3, JP Jouany 2, M Chavarot 1, F Bonnemoy 1-3, \\ $P$ Gouet 1 \\ 1 INRA, Laboratoire de Microbiologie, 63122 Saint-Genès-Champanelle; \\ 2 Station de Recherches sur la Nutrition des Herbivores, Unité Digestion Microbienne, \\ 63122 Saint-Genès-Champanelle; \\ ${ }^{3}$ CNRS, Laboratoire de Biologie Comparée des Protistes, \\ UA 138 - Université Clermont II, 63170 Aubière, France
}

(Received 17 December 1990; accepted 25 April 1991)

\begin{abstract}
Summary - The development of the rumen digestive functions was studied in lambs placed in sterile isolators at $1,4,8$ or 9 days of age to define the role of the bacterial species that colonize the rumen just after birth. The values of the main rumen digestive parameters $(\mathrm{pH}$, concentrations of volatile fatty acid, ammonia, lactic acid) in these lambs were close to those observed in conventional controls. Likewise, the digestive utilisation of the dry matter and starch was comparable in isolated and control animals but the digestibility of crude cellulose was higher in isolated lambs, which harboured only Fibrobacter succinogenes as the sole cellulolytic bacterial species. These results suggest that the rumen flora of the very young lamb play an essential role in the establishment of the rumen ecosystem and in the setting up of the digestive functions.
\end{abstract}

lamb / rumen / microflora / digestion

Résumé - Développement des fonctions digestives du rumen chez des agneaux placés en isolateurs stériles quelques jours après la naissance. Le développement des fonctions digestives du rumen a été étudié chez des agneaux conventionnels placés en isolateurs stériles à l'áge de $1,4,8$ et 9 jours afin de préciser le rôle des espèces bactériennes qui colonisent le rumen juste après la naissance. Chez ces agneaux, les valeurs des principaux paramètres de la digestion ruminale $(\rho \mathrm{H}$, concentrations en acides gras volatiles, ammoniac, acide lactique) ont été proches de celles mesurées chez des agneaux conventionnels témoins. De même, les coefficients d'utilisation digestive de la matière sèche et de l'amidon ont été comparables chez les isolés et les témoins mais la digestibilité de la cellulose brute a été beaucoup plus élevée chez les isolés hébergeant Fibrobacter succinogenes comme seule espèce cellulolytique. Ces résultats démontrent le rôle essentiel de la flore du rumen du très jeune agneau dans l'aménagement de l'écosystème ruminal et dans la mise en place des fonctions digestives. 


\section{INTRODUCTION}

The rumen of lambs (Fonty et al, 1987) and calves (Bryant et al, 1958; JayneWilliams 1979; Anderson et al, 1987) is rapidly colonized after birth by an abundant and complex bacterial population. By the second day of life, the bacteria are found in a concentration close to that observed in mature ruminants with strictly anaerobic species being predominant. The cellulolytic bacteria and the methanogens appear progressively during the first week of life while the anaerobic fungi and the ciliate protozoa become established within 8-10 days and 15-20 days after birth respectively (Fonty et al, 1987, 1988c).

The role of the bacterial species colonizing the rumen just after birth when it is not yet functional has not been established. However, it may be assumed that this microflora is involved in the organisation of the rumen physiology and the development of rumen digestive functions. To define the role of this microflora with accuracy, bacterial contamination must be suppressed and the animals kept in a constant biotic and abiotic environment. To achieve these conditions, naturally born lambs were placed in sterile isolators a few days after birth. The objectives of our study were; 1), to determine whether or not cellulolytic bacteria could become established in the rumen of these animals; 2), to compare the development of rumen digestive functions and the digestive utilization of the feed and of its main components in the isolated lambs with those of conventional animals. The establishment of cellulolytic bacteria has previously been described (Fonty et al, 1989). In the present paper results on the digestive parameters are reported and discussed.

\section{MATERIALS AND METHODS}

\section{Animals}

Four groups of lambs, separated from their dam at $24 \mathrm{~h}$ of age but kept in a conventional environment, were transferred to sterile isolators between 1 and 9 days of age: 2 (IA and IB) on day 1,2 (IVA and IVB) on day 4,1 (VIIIA) on day 8 , and 2 (IXA and IXB) on day 9 . They were reared in these isolators until 4 or 5 months of age. While lambs IIIA and IVB naturally harboured a cellulolytic microflora, lambs IA, IB, IXA and IXB which were free of cellulolytic bacteria when placed in sterile isolators, and lamb VIIIA, in which cellulolytic bacteria had disappeared soon after entry, were then inoculated with a pure culture of Fibrobacter (Bacteroides) succinogenes S.85 as previously described (Fonty et al, 1989). Lambs IA and IB were inoculated on day 19, 24 and 27, VIIIA on day 29, and IXA and IXB on day 22 and 29.

Lambs isolated at the same age were reared together in the same isolator. Up to 3 weeks of age, they were fed ad libitum on sterile cow milk (UHT) only. They were then given 11 and 500 $\mathrm{ml}$ per day until 7 and 10 weeks of age respectively. From the fourth week of age on, they received a pelleted solid diet (particle size: $7 \mathrm{~mm}$ ) containing (\% w/w): meadow hay, 32.3; barley grain, 27; wheat grain, 10; dried beet pulp, 4; peanut meal, 21.7; glucose 3.3; molasses, 1 ; vitamin and mineral supplement, 0.7 .

Two lambs fed the same diet but reared with their dam until weaning (day 42) were used as controls.

\section{Samplings of rumen contents}

Samples of rumen contents were withdrawn by stomach tube from all lambs except for IXA and IXB which were fitted with a pemanent rumen cannula at 6 days of age. During the period 2050 days of age, the lambs were sampled just before the morning feed. Thereafter, because the animals ingested their feed in a real meal, they 
were sampled just before the morning feed $\left(T_{0}\right)$ and $2 \mathrm{~h}$ later $\left(\mathrm{T}_{2}\right)$. Rumen samples were taken twice a week.

\section{Analyses}

From each rumen sample, we measured: $\mathrm{pH}$, volatile fatty acids (VFA) (concentration and centesimal composition), ammonia nitrogen ( $\mathrm{N}$ $\mathrm{NH}_{3}$ ) concentration, ethanol acid and lactic concentrations. Ethanol concentration and VFA were analysed by GLC as described by Jouany (1982). Lactic acid concentration was determined by the same method and $\mathrm{N} \cdot \mathrm{NH}_{3}$ was analysed by the colorimetric method of Van Eenaeme et al (1969).

The digestive utilization of the feed and of its main components was studied in lambs IA, IB, IVA, IVB, and VIIIA by control of the feed intake and total collection of feces during 2 periods of 7 days. The analytic methods used for feed and feces have been described previously (Fonty et al, 1983b).

Statistical tests were performed by a variance analysis. Means were compared by the Student parametric test (Lebart et al, 1979).

\section{RESULTS}

\section{Evolution of the rumen digestive parameters with animal age}

The level of solid feed intake was lower in isolated than in conventional animals (fig 1). Of the isolated lambs, VIIIA reared alone, and IA and IB, which were isolated the earliest, had the smallest appetites.

In all isolated animals $\mathrm{pH}$ values of the rumen contents were close to those measured in controls. They were around neutrality before the lambs had eaten (6.9-7.1) and between 1.5 and 2 units lower $2 \mathrm{~h}$ after the beginning of the meal (table I).

Volatile fatty acid (VFA) concentrations in all isolated lambs were close to those measured in conventional control animals

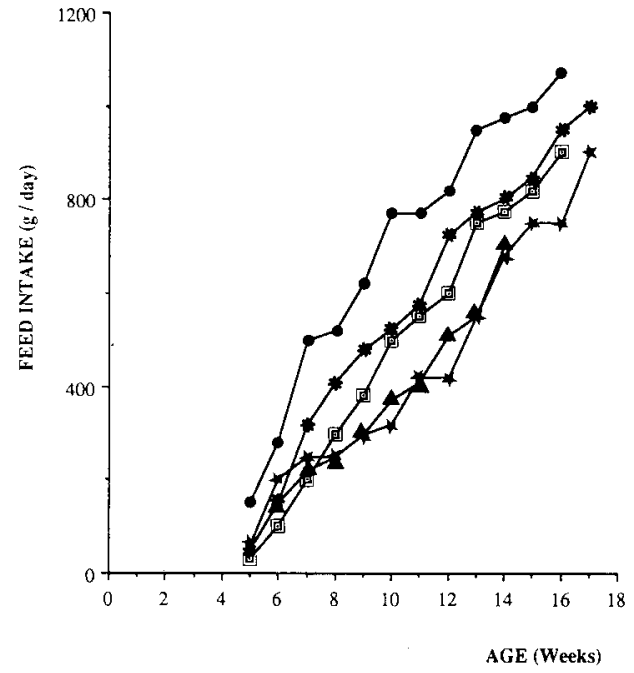

Fig 1. Feed intake of lambs transferred into isolators a few days after birth and that of conventional control lambs. A : IA-IB; : IVA-IVB; $\star$ : VIIIA;回: IXA-IXB; : controls.

(table I). After weaning they ranged on av-

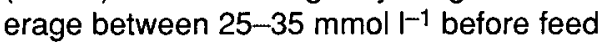
intake and between 70 and $90 \mathrm{mmol} \mathrm{I}^{-1}$ two $h$ after. No significant differences were observed between the groups of animals.

In contrast the molar composition of the VFA mixture varied according to the group of animals. Before weaning (ie, 20-50 days of age), there was a larger proportion of acetic acid in the mixture of VFA from animals $I A$ and $I B$ than in the other 2 groups of isolated lambs (fig 2). Afterwards the proportion of acetate in animals $I A$ and IB was close to that observed in the controls. In all isolated animals, and in particular in those isolated at 4, 8 and 9 days the proportion of propionic acid was greater than that of the control animals. After weaning (ie 70-120 days of age), the proportion of acetic acid, $2 \mathrm{~h}$ after feeding, remained higher in isolated animals than in the controls. The younger the lambs were isolated, the higher the proportion of acetic acid. 


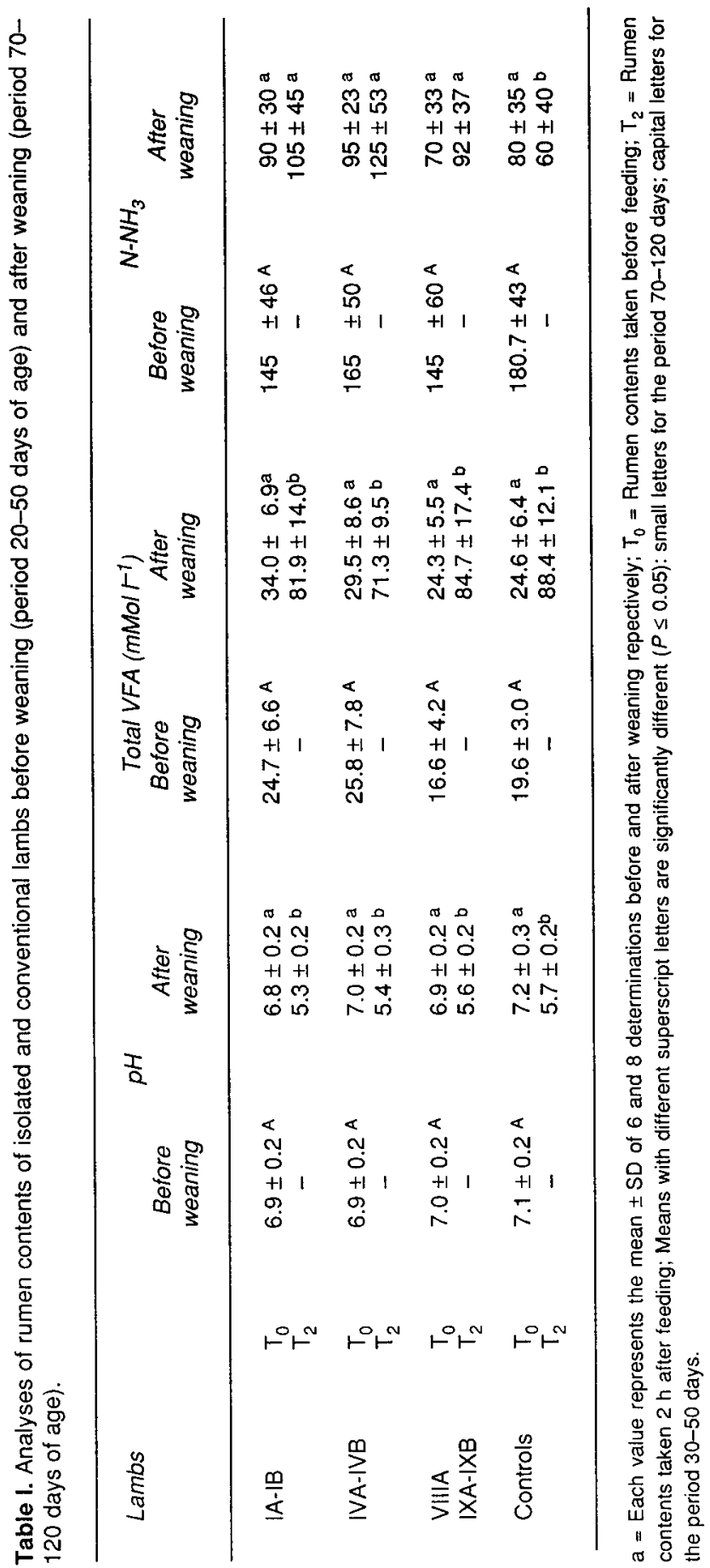



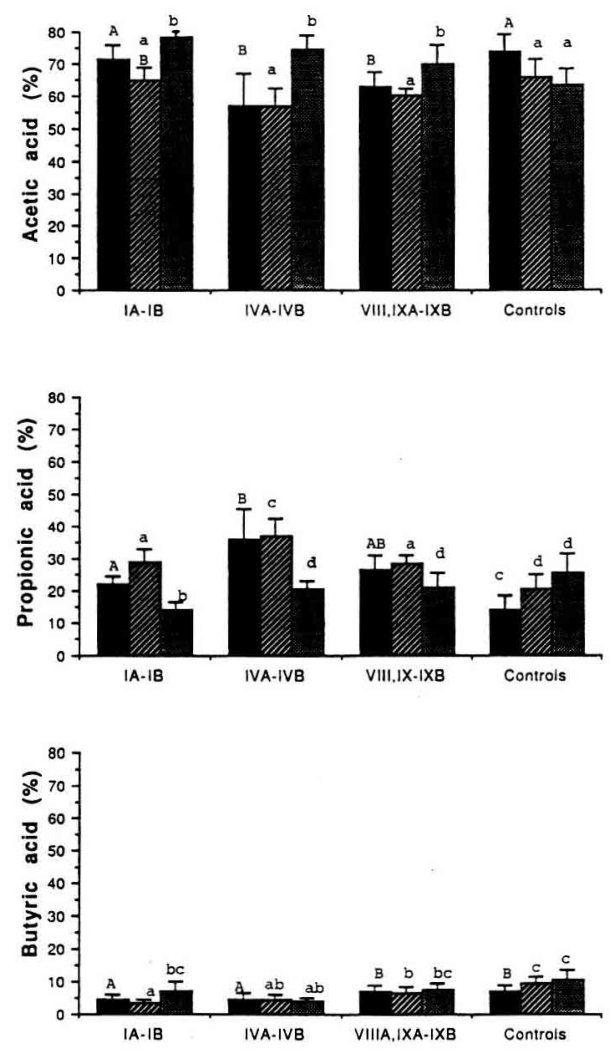

Fig 2. Centesimal composition of the VFA mixtures in the rumen of isolated and conventional lambs. period: $20-50$ days of age; period : 70120 days of age, before feeding $\left(T_{0}\right)$; period: $70-120$ days of age $-2 \mathrm{~h}$ after feeding $\left(\mathrm{T}_{2}\right)$. Each value represents the mean $\pm S D$ of 6 and 8 determinations before and after weaning respectively. Means with different superscript letters are significantly different $(P \leq 0.05)$ (small letters for the period 70-120 days, capital letters for the period 20-50 days).

In all groups studied, there were large differences in the ammonia nitrogen concentration between animals (table $I$ ) and also considerable individual variations. In both isolated and control lambs the concentrations were higher before than after weaning. Differences were particularly marked in the latter group of animals.

The lactic acid concentration in isolated lambs IVA, IVB, VIII and IXA, as in conventional animals, was always very low or nil $\left(0-1 \mathrm{~g} \mathrm{I}^{-1}\right)$. In lambs IA and IB, isolated at $24 \mathrm{~h}$, the concentration was slightly higher (2-3 $\left.\mathrm{g}^{-1}\right)$. In both isolated and control animals ethanol was present only as traces.

\section{Digestive utilization of the feed and of its main components}

There was little difference in the total tract digestion of dry matter and starch between isolated lambs (table II) and no change in the 40 days separating the 2 periods of measurement. Results were comparable to those observed in conventional animals.

In lambs IVA and IVB, which harboured cellulolytic flora when they were isolated, the digestibility of crude cellulose was comparable to that measured in conventional animals and, as in the latter, it was higher during the second period. In contrast, cellulose digestibility in lambs IA and VIIIA, which were inoculated with $F$ succinogenes, was higher than in conventional animals and in lambs IVA and IVB.

\section{DISCUSSION}

In a previous study (Fonty et al, 1989), we showed that cellulolytic bacterial species, $F$ succinogenes in IA, IB, VIIIA, IXA and $I X B$, and a mixed population in IVA and IVB, can establish and remain stable whereas it is extremely difficult, if not impossible, for these same species to become established in gnotoxenic lambs, whose rumen microflora is too simplified (Mann and Stewart 1974; Lysons et al, 1976; Hobson et al, 1981; Fonty et al, 1983a; Fonty et al, 1988a). The microflora 
Table II. Intake and digestibility (\%) of the diet measured in all the digestive tract in the isolated and control lambs.

\begin{tabular}{lcccccc}
\hline Lambs & $\begin{array}{c}\text { Period } \\
\text { (days) }\end{array}$ & $\begin{array}{c}\text { Feed intake } \\
\left(D M . g^{-1} \cdot d^{-1}\right)\end{array}$ & $\begin{array}{c}\text { Dry matter } \\
\text { digestion }(g / \text { day) }\end{array}$ & $\begin{array}{c}\text { Dry matter } \\
\text { digestibility } \\
(\%)\end{array}$ & $\begin{array}{c}\text { Starch } \\
\text { digestibility } \\
(\%)\end{array}$ & $\begin{array}{c}\text { Crude } \\
\text { cellulose } \\
\text { digestibility (\%) }\end{array}$ \\
\hline IA & $83-90$ & 560 & 400 & 68 & 98 & 44 \\
IVA-IVB & $65-72$ & 520 & 330 & $59 \pm 1.0$ & $97 \pm 0.1$ & $30 \pm 3$ \\
& $102-109$ & 750 & 430 & $61 \pm 2.0$ & 97 & $37 \pm 0.5$ \\
VIIIA & $65-72$ & 350 & 250 & 70 & 98 & 55 \\
& $102-109$ & 650 & 450 & 67 & 97 & 47 \\
Controls & $65-72$ & 720 & 430 & $60 \pm 0.7$ & $97 \pm 0.1$ & $32 \pm 4$ \\
& $102-109$ & 950 & 600 & $64 \pm 3$ & $97 \pm 0.1$ & $35 \pm 4$ \\
\hline
\end{tabular}

harboured by the lambs at the time they were isolated was also sufficiently diversified to allow uneventful weaning and satisfactory feed intake. The amounts ingested by the isolated animals were, however, lower than in the conventional controls. In meroxenic lambs, it has been shown that solid feed intake is also closely related to the complexity of the rumen microflora (Fonty et al, 1983b).

The fermentative metabolite concentrations in the rumen contents of isolated lambs were close to those of holoxenic animals, which shows that there was normal fermentive activity in their rumen. The slight differences observed in the centesimal composition of the VFA of the different groups may be linked to differences in the qualitative composition of the microflora (Fonty et al, 1989). The kinetics of establishment of cellulolytic bacteria were much more irregular and slower in isolated lambs than in the conventionally-reared lambs. In the latter, cellulolytic bacteria were present in high numbers from the end of the first week onward while in all isolated animals their number varied considerably during the first 2 months (Fonty et al, 1989). These fluctuations are attributable to a less stable ecosystem. The composition of the cellulolytic bacterial population also differed between groups. Lambs IA-IB, VIIIA, IXA-IXB harboured only $F$ succinogenes $\$ 85$ while lambs IVA-IVB and controls harboured a more diversified cellulolytic flora (Fonty et al, 1989). Differences in the qualitative composition of the dominant rumen flora between isolated and conventionally reared lambs were observed when several bacterial populations were enumerated on specific culture media containing a single energy source (Fonty et al, 1989).

In lambs IA and VIIIA, $F$ succinogenes $S-85$, the only cellulolytic strain present, degraded a larger proportion of crude cellulose than the complex and complete cellulolytic flora of the conventional animals and of lambs IVA and IVB. The larger cellulolytic population in IA and VIIIA (108-109 bacteria $\mathrm{ml}^{-1}$ as against $10^{7}-10^{8}$ bacteria $\mathrm{ml}^{-1}$ in the other animals) may account for this greater effectiveness (Fonty et al, 1989) together with the intense cellulolytic activity accredited to $F$ succinogenes in general and to strain $S 85$ in particular, the 
strain used in these experiments which is capable of degrading highly crystalline cellulose and other types of hemicelluloses (Halliwell and Bryant 1963; Fonty et al, 1988b; Stewart and Flint, 1989).

The greater decrease in $\mathrm{NH}_{3}-\mathrm{N}$ in the rumen of control animals after weaning compared to isolated animals indicated that the bacterial population in controls used $\mathrm{NH}_{3}-\mathrm{N}$ more effectively for proteosynthesis. This was confirmed by the decrease in $\mathrm{NH}_{3}-\mathrm{N}$ concentration observed after feed intake during the 70-120 day period. The presence of lactic acid in lambs $\mathrm{IA}$ and IB, isolated at one day of age, shows that the flora is not able to completely metabolize this intermediate product. This probably means that these animals, in comparison with the other, harbor a very simple microflora.

In conclusion, these results show that the bacterial species that colonise the rumen immediately after birth, when this organ is not yet functional, play an essential role: they prepare a biotope favourable to the establishment of cellulolytic strains and set up the digestive processes that affect both the degradation of the lignocellulosic rich feeds and the fermentation of the resulting soluble compounds. However, the greater cellulose degradation was not accompanied by an increase in VFA concentration. It is also possible that in these lambs cellulose breakdown took place partly in the large intestine since digestibility was measured all along the digestive tract.

\section{ACKNOWLEDGMENTS}

The authors wish to thank $G$ Andant, $P$ Journaix and MP Girard for skilled technical assistance.

\section{REFERENCES}

Anderson KL, Nagaraja TG, Morill JL, Avery TB, Galitzer SJ and Boyer JE (1987) Ruminal microbial development in conventionally or early weaned calves. J Anim Sci 64, 1215-1226

Bryant MP, Small N, Bouma C, Robinson IM (1958) Studies on the composition of the ruminal flora and fauna of young calves. $J$ Dairy Sci 41, 1747-1767

Fonty G, Gouet P, Jouany JP, Senaud J (1983a) Ecological factors determining the establishment of cellulolytic bacteria and protozoa in the rumen of meroxenic lambs. $J$ Gen Microbiol 129, 213-223

Fonty G, Jouany JP, Thivend P, Gouet P, Senaud $J(1983 b)$ A descriptive study of rumen digestion in meroxenic lambs according to the nature and complexity of the microflora. Reprod Nutr Dev 23, 857-873

Fonty G, Gouet P, Jouany JP, Senaud J (1987) Establishment of the microflora and anaerobic fungi in the rumen of lambs. $J$ Gen Microbiol 133, 1835-1843

Fonty G, Forano E, Gaudet G, Komisarczuk S, Gouet P (1988a) Données nouvelles sur les bactéries cellulolytiques du rumen. Reprod Nutr Dev 28 (suppl 1), 19-32

Fonty G, Gouet P, Jouany JP (1988b) Establishment of Bacteroides succinogenes and measurement of the main digestive parameters in the rumen of gnotoxenic lambs. Can J Microbio/ 34, 39-46

Fonty G, Senaud J, Jouany JP, Gouet P (1988c) Establisment of the ciliate protozoa in the rumen of conventional lambs. Influence of diet and management conditions. Can J Microbiol 34, 235-241

Fonty G, Gouet P, Nebout JM (1989) Development of the cellulolytic microflora in the rumen of lambs transferred into sterile isolators a few days after birth. Can J Microbiol 35 , 416-422

Halliwell G, Bryant MP (1963) The cellulolytic activity of pure strains of bacteria from the rumen of cattle. J Gen Microbio/ 32, 441-448

Hobson PN, Mann SO, Stewart CS (1981) Growth and rumen function of gnotobiotic 
lambs fed on starchy diets. $J$ Gen Microbiol $126,219-230$

Jayne-Williams DJ (1979) The bacterial flora of the rumen of healthy and bloating calves. $J$ Appl Bacteriol 47, 271-284

Jouany JP (1982) Volatile fatty acid and alcohol determination in digestive contents, silage juices, bacterial cultures and anaerobic fermentor contents. Sci Alim 2, 131-144

Lebart L, Morineau A, Fenelon JP (1979) Traitement des Données Statistiques. Méthodes et Programmes. Dunod-Bordas, Paris, 520 pp

Lysons RJ, Alexander TJL, Wellstead PD, Hobson PN, Mann SO, Stewart CS (1976) Defined bacterial population in the rumen of gnotobiotic lambs. J Gen Microbiol 94, 257269
Mann SO, Stewart CS (1974) Establishment of a limited rumen flora in gnotobiotic lambs fed on a roughage diet. J Gen Microbiol 84, 379382

Michel M (1971) Analyses quantitatives de quelques substances azotées et glucidiques en milieu biologique. Essai de rationalisation. Thèse, Université de Clermont-Ferrand

Stewart CS, Flint JH (1989) Bacteroides (Fibrobacter) succinogenes, a cellulolytic anaerobic bacterium from the gastro-intestinal tracts. Appl Microbiol Biotechnol 30, 433-439

Van Eenaeme C, Bienfait IM, Lambert O, Pondant $A$ (1969) Détermination automatique de l'ammoniaque dans le liquide du rumen par la méthode de Berthelot adaptée à l'autoanalyser. Ann Med Vet 113, 419-423 